\title{
Is Efficient to Play in First Division? Influence of Promotion and Relegation in the Technical Efficiency of the Spanish Professional Football Teams
}

\author{
Ana María Magaz González ${ }^{*}$, Fernando Mallo Fernández² and José Luis Fanjul Suárez² \\ ${ }^{1}$ Departamento de Didáctica de la Expresión Musical, Plástica y Corporal, Universidad de Valladolid, España \\ ${ }^{2}$ Departamento de Dirección y Economía de la Empresa, Universidad de León, España
}

*Corresponding author: Ana María Magaz González, Departamento de Didáctica de la Expresión Musical, Plástica y Corporal, Universidad de Valladolid, Campus Universitario Duques de Soria, 42004 Soria, España

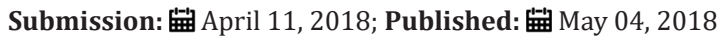

\begin{abstract}
The aim of this article is to know at which level a club is more efficient and how promotion and relegation affects technical efficiency. The sample consists of clubs that played at least one season in the First Division in Spanish Professional Football League between seven seasons. The method for calculating technical efficiency is Data Envelopment Analysis and this is combined with the study of trend and stability to ensure the correct choice of model and to check the robustness of the results. Our conclusion is that teams that have promoted and relegated are more efficient. These clubs improve their technical efficiency after being relegated and staying in the lower category. It is necessary to pursue its optimal positioning depending on its sporting potential and its economic financial capacity but not necessarily the promotion. We suggest that the Spanish Football League review the conditions and format to promotion.
\end{abstract}

Keywords: Technical efficiency; Data envelopment analysis; Trend and stability; Spanish professional football league; Promotion and relegation

\section{Introduction}

The study of efficiency is useful for knowing to what extent management is adequate. With regard to sports organizations, research into how the sporting production function determines the efficiency of the club has been conducted as well as strategic decision making in terms of both sporting factors and investments. In the Spanish Professional Football League (LFP), access to the first division $\left(1^{\text {st }} \mathrm{D}\right)$ is open to all clubs that meet the sporting and financial requirements. In LFP, there is a group of clubs that have successively been promoted to the $1^{\text {st }} \mathrm{D}$ but are then relegated to the Second Division A $\left(2^{\text {nd }} A\right)$. These clubs are referred to as "elevator teams". Their continual back and forth between levels entails efforts at a budgetary level to cope with the demands of $1^{\text {st }} \mathrm{D}$, and in many cases, financial imbalances and changes in their efficiency level.

This article analyses efficiency in Spanish professional football: how promotions and relegations affect to efficiency, the relationship between efficiency and sporting success and, if it is effective to play in $1^{\text {st }} \mathrm{D}$ or to remain in $2^{\text {nd }} \mathrm{A}$. This article is structured as follows: Section two describes the particularities of professional football in Spain from an economic and sporting point of view. Section three summarizes the state of the issue. Section four establishes the methodology and sample used in researching efficiency. Section five explains the results of the study of the efficiency of professional clubs. The article ends with a discussion of results, along with conclusions and proposed actions with regards to the LFP.

\section{Traits of Spanish Professional Football}

The investors in Sociedades Anónimas Deportivas or SAD have not only sought to maximize profit. Rather, their main objective has been to achieve the best sports results to allow them to remain at their current levels, trying to incur the fewest possible losses $[1,2]$ and to derive psychological return in terms of the success of the club. In the Spanish league competition, sporting triumphs are those that allow a club to remain in $1^{\text {st }} \mathrm{D}$, where revenues are higher. As a result, clubs attempt to maximize $[3,4]$ as a means to make a profit. The sporting successes are built principally upon the specific resources of players and the coach [5]. Thus, when the club is more invested in its players, there is a greater guarantee of sporting success in the long run. With this success comes greater revenue, which allows access to better players. Soriano [6] refers to this as the "virtuous circle of football", and Magaz-González [7] has designed a competition model in which the relationships between sporting success, market share and access to specific resources are brought together.

These authors note the significant economic and financial efforts to improve their squads, preserve competitive capacity and 
obtains the best sporting results. When their priorities are not focused on maximizing the cost-benefit function, high indebtedness is generated. This investment policy is a risky one because it does not guarantee success on the field or continued $1^{\text {st }} \mathrm{D}$ status, so the sector is placed in situations of financial stress [5,8,9]. Relegation to $2^{\text {nd }} A$ reduces possibilities of revenue from television rights, competition money and box office receipts by a fivefold or six-fold and the market share shrinks. Although budgets should be adjusted to this new situation, many clubs attempt to return to the $1^{\text {st }} \mathrm{D}$ by strengthening their squads, increasing financial stress even further. The result is that many clubs are inefficient, insolvent and bankrupt. Therefore, the following should be required: to be profitable at the same time as efficient [10] and successful in sporting terms, and identify the appropriate and sustainable position of each club. With this in mind it is important to examine the efficiency in Spanish professional football and how promotions and relegations affect efficiency.

\section{Research in Efficiency in Football Teams}

In the research in efficiency in sports two models are observed. Model of industry efficiency, which has been applied by Porter \& Scully [11], Haas et al. [12], Espitia-Escuer \& García-Cebrián [13] and Barros \& Leach [14] and the stochastic frontier models which have been applied by Dawson et al. [15], Carmichael et al. [16], Gerrard [17]. At the same time, two approaches of model of industry efficiency exist. The first is from a strategic viewpoint [18]. This refers to the difference in efficiency is determined by structural market conditions-such as barriers to entry, exit and mobility and bargaining power in relation to competitors, customers and distributors-that the organization must face and that produce different performance levels. Not all teams in the LFP can handle such conditions with the strategic options available to them, which affects efficiency. The second theoretical framework is the ResourceBased View (RBV) [19-23], which establishes that either a variation in possession of resources, the quality of their management or the way in which they are organized determines efficiency. In football that use highly specialized resources, not all clubs have easy access to resources due to their high cost. Additionally, although resources may be similar, there may be variation in the quality of the production process or how they are organized.

Whether in regards to the American model of sport or the European one, most works that evaluate the efficiency of different sports and leagues do so by analysing the "sporting production function" [13,15,24-27]. They take the following as outputs: wins, goals scored, points won, position achieved in the Spanish league competition, points not won out of the total possible points. The inputs used are those related to the performances of the players in different tasks or tasks inherent to the individual and collective ability, fitness and experience of the players [8,24]: shots at a goal, minutes of possession, recoveries of the ball made, crosses made into the area of the opposition [28], and other technical elements of the game. Other studies use economic-financial information and they take the following as inputs and outputs: the cost of the primary resource (players) or depreciation charges as a supposed measure of the abilities of the players to achieve sporting performance; the influence of these and other costs on total revenue; wages and transfer spending and sales [29]; personnel costs [30] or net profit [31].

Many of these researchers conclude that the possession of highly valuable resources or the use of certain playing systems is not always synonymous with achieving a good league position and ensuring another season in the 1st D. Rather, they conclude that efficiency is in making an efficient use of these elements and in the quality of management of its "technology" [10]. Pestana et al. [32] conclude that resources, organizational structure and economies of scale are important factors in the efficiency of a club and that it is therefore not a question of sporting aspects alone. They identify heterogeneous variables for the determination of the cost of production to be able to compare the economic efficiency with the sporting efficiency. In addition, the production process of "scoring goals" is very similar among all participants; as a result, their different levels of efficiency may be due to other elements that are not necessarily sport related. Guzmán [30] concludes that by organizing resources and adapting their financial structure, clubs should be able to achieve optimum levels of efficiency and sustainable growth. Along these lines, conditions change upon relegation to $2^{\text {nd }} A$. Relegation creates a barrier to exit, owing to the decline in revenue and the consequences on the ability of the team to address debts. A quick promotion back to the $1^{\text {st }} \mathrm{D}$ becomes a need to recover the ability to generate revenue; additionally, it becomes more difficult to meet the cost of acquiring valuable resources to attempt to win promotion. Upon being relegated, teams tend to restructure themselves since the budgetary adjustments affect the recruitment of players and technical staff; in addition, the capacity to manage and organize the team must be adapted. However, none of these jobs evaluates what happens to efficiency whit relegation to $2^{\text {nd }} A$.

Taking into account these perspectives, the novel aspects of this research are that it investigates how promotions and relegations affect efficiency, how teams are positioned around the efficient frontier according to whether they are "follower" or "elevator" teams and at one level or another. The division of the study population into two subsamples does not appear in any other work. Finally, to select inputs and outputs, we employed heterogeneous factors and variables that encompassed information on sporting factors, economic-financial factors, and organizational structure and functioning and environmental exploitation.

\section{Methodology and Sample}

Technical efficiency consists of maximizing the level of output that can be obtained from a given combination of inputs. That is, it indicates the degree of success in the use of productive resources. In this study, efficiency has been estimated using DEA (Data Envelopment Analysis) applied to organizational units. DEA units are referred to as decision-making units (DMU), and in this study, every football club in each season represents a single DMU. Based on nonparametric techniques using the input and output 
quantities consumed and produced, DEA constructs that are based on the "best practice" observed, the efficient frontier of production, and the relation to which technical efficiency and the distance to the frontier of each DMU (clubs) are evaluated. Through this, the clubs that operate at maximum efficiency are identified, with those outside the reference frontier being inefficient.

The model to solve is the following [33]:

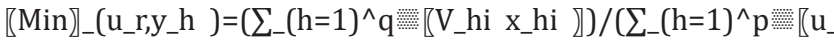
hi $y_{-}$hi $\left.\llbracket\right], \forall_{-} i=1, \ldots . ., n$

Subject file 1

$\left(0 \leq\left(\sum_{-}(\mathrm{r}=1)^{\wedge} \mathrm{p}\right.\right.$ : 』) $\leq 1, \forall_{-} \mathrm{i}=1, \ldots . ., \mathrm{n} @ \mathrm{u}_{-}$ri $\geq 0$ yv_hi $\geq 0$,para $\left.\mathrm{r}=1, \ldots . \mathrm{p} ; \mathrm{h}=1, \ldots \mathrm{q}\right) \dashv$

Where $y_{r i}$ is the value of the output variable $y_{r}$ in DMU $i^{\text {th }}$ for $r=1, \ldots . p ; x_{h i}$ is the value of the input variable $x_{h}$ in DMU $i^{\text {th }}$ for $h=1, \ldots q$; $\mathrm{u}_{\mathrm{ri}}$ is the weight of output variable $\mathrm{r}^{\text {th }}$ in DMU $\mathrm{i}^{\text {th }} ; \mathrm{V}_{\mathrm{hi}}$ is the weight of input variable h-th in DMU $i^{\text {th }}$; and $\mathrm{n}$ is the number of decision's units, DMU.

Analysis with an orientation towards outputs is used since our aim was to estimate maximum levels of outputs for given levels of inputs. We used the STATA statistical programme with the DEA package. The DMUs were selected among clubs that played at least one season in the $1^{\text {st }} \mathrm{D}$ during the period of 2004-2011. We excluded teams that played in European competitions since their market concentration; share and size made some variables have extreme values and distorted the results of the sample. In addition, there is evidence in the literature that indicates that participation in European competitions does not affect efficiency [12,34]. The clubs entered into the model are divided into "follower" teams if they always played in the $1^{\text {st }} \mathrm{D}$ (the one to seven teams in the tables) or "elevator" teams (the eight to forty in the tables) if they were relegated to the $2^{\text {nd }} \mathrm{A}$ and then went back up. The sample is

Table 1: Variables selected for the study. composed of 14 teams (seven "followers" and seven "elevators") for seven seasons, generating a total of 98 observations.

To validate the research, we have selected variables used in other research according to data availability. The database also includes some factors identified by authors through Principal Components Analysis (PCA) in a previous study. These factors are related to economic and financial results for teams in the sample. The PCA allows the dimensionality of data to be reduced with the least possible loss of information. The extracted factors were classified into 4 types: productive structure performance, financial performance, economic performance and other factors. These factors collect the most significant results for each sport club. The DEA model is sensitive to the data with which it is analysing, and in this regard, taking into account the theoretical approach, the choice of heterogeneous factors and variables allows uncertainty to be reduced; data can be considered deterministic, and the assumption that the data are accurate, precise and reliable can be made. This prevents unreliable data directly related to sports production (goals, wins, etc.), which can be affected by elements that cannot be controlled or quantified, such as weather, time of the season, injuries or refereeing decisions.

Inputs are those that have impact on the "sporting production function" and those who provide information on economic and financial conditions and strategic options: experience, staffing strategy, expenses or depreciation charges, decisions on liquidity, production strategy, brand exploitation strategy, as well as inputs of the structure, as capital. All of them show the sports and economic behaviour of a club. The outputs reflect different dimensions of the results of sporting performance: points won, as well as economicfinancial results: profitability achieved survivability, brand image enhancement, and so forth. They can be found in Table 1. The descriptive statistics for the variables used in this study for each club between 2004 and 2011 is shown in Table 2 .

\begin{tabular}{|c|c|c|}
\hline Season & Inputs & Outputs \\
\hline \multirow{2}{*}{1} & RL1 Liquidity ratio & PUNTOS1 Points in ranking \\
\hline & FAC1_1 Efficacy of the production strategy for the brand & FAC2_1 Financial independence \\
\hline \multirow{2}{*}{2} & DAI2 Investment in players & PUNTOS2 Points in ranking \\
\hline & GPT2 Personnel expenses & FAC3_2 Economic Efficiency of society \\
\hline \multirow[b]{2}{*}{3} & C3 Share Capital & PUNTOS3 Points in ranking \\
\hline & DAI3 Investment in players & $\begin{array}{l}\text { FAC1_3 Strengthening brand financial sustainability guarantee of the } \\
\text { club }\end{array}$ \\
\hline \multirow{2}{*}{4} & EXP4 Experience in First Division & PUNTOS4 Points in ranking \\
\hline & FAC2_4 Efficacy with staffing strategy & FAC3_4 Financial independence brand strength \\
\hline \multirow{2}{*}{5} & EXP5 Experience in First Division & PUNTOS5 Points in ranking \\
\hline & FAC1_5 Efficacy of the production strategy & RDOEXP5 Return of Exploitation \\
\hline \multirow{2}{*}{6} & EXP6 Experience in First Division & PUNTOS6 Points in ranking \\
\hline & GPT6 Personnel expenses & FAC1_6 Economic Efficiency productive Br strength investment \\
\hline \multirow{2}{*}{7} & EXP7 Experience in First Division & PUNTOS7 Points in ranking \\
\hline & C7 Share Capital & FAC1_7 Financial economic strength of society \\
\hline
\end{tabular}


Table 2: The descriptive statistics for the variables used in this study for each club between 2004 and 2011.

\begin{tabular}{|c|c|c|c|c|}
\hline & Minimum & Maximum & Average & SD \\
\hline RL1 & 0,32 & 2,92 & 0,92 & 0,85 \\
\hline FAC1_1 & $-1,32$ & 2,53 & 0,00 & 1,00 \\
\hline PUNTOS1 & 37,00 & 71,00 & 51,43 & 9,65 \\
\hline FAC2_1 & $-1,41$ & 2,07 & 0,00 & 1,00 \\
\hline DAI2 & 560339,00 & 21172394,38 & 5236928,88 & 5457681,82 \\
\hline GPT2 & 5770334,00 & 32580993,65 & 176866664,65 & 7440879,67 \\
\hline PUNTOS2 & 24,00 & 78,00 & 50,36 & 14,83 \\
\hline FAC3_2 & $-1,39$ & 1,65 & 0,00 & 1,00 \\
\hline $\mathrm{C} 3$ & 98301,15 & 16861094,02 & 6585020,18 & 4676153,79 \\
\hline DAI3 & 315851,00 & 48981864,30 & 7663602,14 & 12208738,90 \\
\hline PUNTOS3 & 35,00 & 88,00 & 50,50 & 12,71 \\
\hline FAC1_3 & $-2,45$ & 2,19 & 0,00 & 1,00 \\
\hline EXP4 & 1,00 & 4,00 & 3,36 & 1,01 \\
\hline FAC2_4 & $-1,87$ & 1,79 & 0,00 & 1,00 \\
\hline PUNTOS4 & 26,00 & 72,00 & 50,21 & 11,65 \\
\hline FAC3_4 & $-2,86$ & 1,30 & 0,00 & 1,00 \\
\hline EXP5 & 2,00 & 5,00 & 4,14 & 1,10 \\
\hline FAC1_5 & $-1,91$ & 1,48 & 0,00 & 1,00 \\
\hline PUNTOS5 & 33,00 & 81,00 & 51,14 & 12,69 \\
\hline RDOEXP5 & $-30050590,65$ & $-3281,76$ & $-9210324,45$ & 7895362,42 \\
\hline EXP6 & 3,00 & 6,00 & 4,86 & 1,35 \\
\hline GPT6 & 1425966,00 & 45600315,36 & 21217448,25 & 12132094,07 \\
\hline PUNTOS6 & 36,00 & 74,00 & 52,43 & 13,33 \\
\hline FAC1_6 & $-2,21$ & 1,50 & 0,00 & 1,00 \\
\hline EXP7 & 3,00 & 7,00 & 5,64 & 1,60 \\
\hline $\mathrm{C} 7$ & 1095920,00 & 37545912,40 & 9398931,01 & 10159481,74 \\
\hline PUNTOS7 & 43,00 & 83,00 & 51,21 & 11,31 \\
\hline FAC1_7 & $-1,57$ & 1,85 & 0,00 & 1,00 \\
\hline $\mathrm{N}$ valid & 14 & & & \\
\hline
\end{tabular}

Efficiency indexes over time may be the result of comparing different facets that the DMU collects during different periods, something which justifies our use of different elements to measure efficiency in different periods. To ensure the correct choice of the model and to check the robustness of the DEA results, we carried out complementary trend and stability tests. These analyses are based on the use of rank statistics, as suggested by Brockett et al. [35]. When are evaluated simultaneously performance of a group of DMUs over time, it is important to detect if there are significant trends in the efficiency ratings whit the select observations or in other key variables. To detect trends in the efficiency ratings, we used the S statistic [35]:

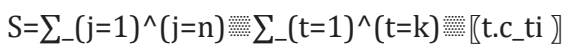

Where $\mathrm{j}=1, \ldots \mathrm{n}$, show the DMUs; $\mathrm{t}=1, \ldots \mathrm{k}$, show the time periods; $\mathrm{Ctj}$ = show the rank statistic obtained by ordering the score DEA in an ascending order.

Following these authors, we transferred the results extracted from DEA into an ascending ordered range based on the relative classification of positions of efficiency for each DMU. The S statistic was identified and a correlation between the time index and the range value was sought to detect trends through the normalization of the statistic. To transform the test statistic $S$ in a normal distribution we use $\mathrm{Z}=(\mathrm{S}-\mu) / \sigma$. The null hypothesis is that there is no trend in the efficiencies observed over time. To confirm the stability of the results over time and know the relative position of DMUs vis-á-vis each other across the whole period we apply the null hypothesis that all DMUs (teams) have the same distribution of DEA ratings using the Kruskal-Wallis nonparametric ANOVA test (K-W) as suggested Brockett et al. [35].

\section{Results}

Table 3 shows the results of the DEA for clubs and for each season as well as rankings extracted by the programme for each DMU, describing the efficiency of the professional football clubs in Spain. The DMUs that are situated on the efficient frontier are mostly elevator teams (on 27 occasions) that played in both the $2^{\text {nd }}$ A and the $1^{\text {st }} \mathrm{D}$. Except for Zaragoza, which was only efficient in one 
season, several clubs were efficient for several seasons. The teams of the followers, which stayed in the $1^{\text {st }} \mathrm{D}$, are located in the efficiency zone on 9 occasions; of these, Getafe is located there in 4 seasons and Athletic de Bilbao in 3. Some teams failed to be efficient during the period studied. Table 4 shows the efficiency and ranking and the position achieved in the national football championship. Taking into account the system of promotion and relegation, we considered a bad sporting result to be a finish below the seventeenth position in the $1^{\text {st }} \mathrm{D}$ and below third position in the $2^{\text {nd }} \mathrm{A}[36,37]$.

Table 3: The results of the DEA for clubs and for each season as well as rankings extracted by the programme for each DMU, describing the efficiency of the professional football clubs in Spain.

\begin{tabular}{|c|c|c|c|c|c|c|c|c|c|c|c|c|c|c|}
\hline DMUs & DEA1 & RK1 & DEA2 & RK2 & DEA3 & RK3 & DEA4 & RK4 & DEA5 & RK5 & DEA6 & RK6 & DEA7 & RK7 \\
\hline Atl. Bilbao & 0.7417 & 7 & 1 & $5(1)$ & 1 & $4(1)$ & 0.778 & 12 & 0.6915 & 8 & 1 & 1 & 0.8886 & 7 \\
\hline Deportivo & 0.7183 & 8 & 0.7818 & 8 & 0.623 & 9 & 0.9666 & 9 & 0.8283 & 6 & 0.6351 & 10 & 0.766 & 10 \\
\hline Osasuna & 0.6559 & 12 & 0.966 & 6 & 0.639 & 7 & 0.8549 & 10 & 0.6515 & 11 & 0.581 & 12 & 0.9184 & 6 \\
\hline Getafe & 0.6619 & 11 & 1 & 1 & 1 & $5(1)$ & 1 & 1 & 0.7158 & 7 & 0.7837 & 9 & 1 & 1 \\
\hline Español & 1 & 1 & 0.5256 & 13 & 0.6021 & 10 & 0.8177 & 11 & 0.658 & 10 & 0.5945 & 11 & 0.8466 & 9 \\
\hline Mallorca & 0.5728 & 13 & 0.5512 & 10 & 0.5568 & 12 & 0.9846 & 8 & 0.6598 & 9 & 0.8378 & 7 & 0.9334 & 5 \\
\hline Santander & 0.663 & 10 & 0.9513 & 7 & 0.5681 & 11 & 1 & 1 & 0.6299 & 12 & 0.527 & 14 & 0.6706 & 13 \\
\hline Levante & 0.5211 & 14 & 1 & 1 & 0.4772 & 13 & 0.3801 & 14 & 1 & 1 & 1 & 1 & 1 & 1 \\
\hline Málaga & 0.8118 & 6 & 0.3076 & 14 & 0.625 & 8 & 1 & 1 & 1 & 1 & 1 & 1 & 0.5657 & 14 \\
\hline R.Sociedad & 1 & $5(1)$ & 0.5287 & 12 & 0.3977 & 14 & 1 & 1 & 1 & 1 & 1 & 1 & 0.6765 & 12 \\
\hline Zaragoza & 0.70422 & 9 & 0.596 & 9 & 0.68181 & 6 & 0.65241 & 13 & 1 & 1 & 0.554 & 13 & 0.6795 & 11 \\
\hline Betis & 1 & $4(1)$ & 0.53846 & 11 & 1 & 1 & 1 & $7(1)$ & 0.5185 & 13 & 0.9594 & 6 & 1 & 1 \\
\hline Recreativo & 1 & 1 & 1 & 1 & 1 & 1 & 1 & 1 & 0.49253 & 14 & 0.79942 & 8 & 0.84848 & 8 \\
\hline Valladolid & 1 & 1 & 1 & 1 & 1 & 1 & 1 & 1 & 1 & 1 & 1 & 1 & 1 & 1 \\
\hline
\end{tabular}

Note: Shaded cells: teams in $2^{\text {nd }} \mathrm{A}$

Table 4 (file 2): The efficiency and ranking and the position achieved in the national football championship. Taking into account the system of promotion and relegation, we considered a bad sporting result to be a finish below the seventeenth position in the 1 st $\mathrm{D}$ and below third position in the 2 nd A.

\begin{tabular}{|c|c|c|c|c|c|c|c|c|c|c|c|c|c|c|}
\hline DMUs & 2004- & R. DEA & 2005- & R. DEA & 2006- & R. DEA & 2007- & R. DEA & 2008- & R. DEA & $2009-$ & R. DEA & 2010- & R. DEA \\
\hline & 5 & & 6 & & 7 & & 8 & & 9 & & 10 & & 11 & \\
\hline Atletic de & 9 & 7 & 12 & $5(1)$ & 17 & $4(1)$ & 11 & 12 & 13 & 8 & 8 & 1 & 6 & 7 \\
\hline \multicolumn{15}{|l|}{ Bilbao } \\
\hline Deportivo & 8 & 8 & 8 & 8 & 13 & 9 & 9 & 9 & 7 & 6 & 10 & 10 & 18 & 10 \\
\hline Osasuna & 15 & 12 & 4 & 6 & 14 & 7 & 17 & 10 & 15 & 11 & 12 & 12 & 9 & 6 \\
\hline Getafe & 13 & 11 & 9 & 1 & 9 & $5(1)$ & 14 & 1 & 17 & 7 & 6 & 9 & 16 & 1 \\
\hline Español & 5 & 1 & 15 & 13 & 11 & 10 & 12 & 11 & 10 & 10 & 11 & 11 & 8 & 9 \\
\hline Mallorca & 17 & 13 & 13 & 10 & 12 & 12 & 7 & 8 & 9 & 9 & 5 & 7 & 17 & 5 \\
\hline Santer & 16 & 10 & 17 & 7 & 10 & 11 & 6 & 1 & 12 & 12 & 16 & 14 & 12 & 13 \\
\hline Levante & 18 & 14 & 3 & 1 & 15 & 13 & 20 & 14 & 8 & 1 & 3 & 1 & 14 & 1 \\
\hline Málaga & 10 & 6 & 20 & 14 & 15 & 8 & 2 & 1 & 8 & 1 & 17 & 1 & 11 & 14 \\
\hline $\begin{array}{c}\text { Real } \\
\text { Sociedad }\end{array}$ & 14 & $5(1)$ & 16 & 12 & 19 & 14 & 4 & 1 & 6 & 1 & 1 & 1 & 15 & 12 \\
\hline Zaragoza & 12 & 9 & 11 & 9 & 6 & 6 & 18 & 13 & 2 & 1 & 14 & 13 & 13 & 11 \\
\hline Betis & 4 & $4(1)$ & 14 & 11 & 16 & 1 & 13 & $7(1)$ & 18 & 13 & 4 & 6 & 1 & 1 \\
\hline Recreativo & 5 & 1 & 1 & 1 & 8 & 1 & 16 & 1 & 20 & 14 & 9 & 8 & 13 & 8 \\
\hline Valladolid & 6 & 1 & 10 & 1 & 1 & 1 & 15 & 1 & 16 & 1 & 18 & 1 & 7 & 1 \\
\hline
\end{tabular}

Note: Shaded cells: teams in $2^{\text {nd }} \mathrm{A}$. Underlined: position achieved in $2^{\text {nd }} \mathrm{A}$

The values indicate that half of the teams achieved a better sporting classification than their efficiency levels in every season. The exception was the 2007-2008 season, when 8 clubs either combined a good sporting classification with efficiency or came close to doing so [38]. In other cases, they were either efficient but not successful in sporting terms, or they achieved neither efficiency 
nor optimum sporting results. Analyses carried out to ensure the robustness of the study yielded the following results. In the examination of a statistically significant trend, the S statistic $=2940$, and its corresponding value for a normal distribution is $\mathrm{Z}=36.83$. The $p$ value $=1$, indicating that the null hypothesis can be rejected at a level of $100 \%$ confidence. Therefore, there is a statistically significant trend in the patterns of efficiency of the set of clubs over time. The K-W analysis performed for each of the variables introduced yielded a result of 0.448 , allowing the null hypothesis to be retained. It is therefore accepted that there is stability in the period analysed in each DMU in relation to its ordinal position, and the efficiency is due to each one of them and not to changes in the relative positions of the other DMUs. Both tests indicated that the variables and factors introduced into the DEA adequately showed aspects that reflect efficiency at the clubs of the sample. Another result extracted from the previous tables is the number of efficient teams in each season and the divisions in which they played. With this analysis, it is possible to deduce if it is efficient to play in the $1^{\text {st }}$ D or not. This is summarized in Table 5.

Table 5 (file 3): Number of efficient teams by category season.

\begin{tabular}{|c|c|c|}
\hline Season & Efficient Teams & $\begin{array}{c}\text { Relationship Efficient } \\
\mathbf{1}^{\text {st }} \mathbf{D} / \mathbf{2}^{\text {nd }} \mathbf{A}\end{array}$ \\
\hline 1 & 5 & $03-\mathrm{Feb}$ \\
\hline 2 & 5 & 02-Mar \\
\hline 3 & 5 & $04-\mathrm{Jan}$ \\
\hline 4 & 7 & $05-\mathrm{Feb}$ \\
\hline 5 & 5 & 02-Mar \\
\hline 6 & 5 & 03-Feb \\
\hline 7 & 4 & $02-\mathrm{Feb}$ \\
\hline
\end{tabular}

Of the 36 efficient teams in the studied seasons, 21 played in the $1^{\text {st }} \mathrm{D}(58.33 \%)$. In two seasons, those of the $2^{\text {nd }} A$ were more productive, and in another, there were an equal number of efficient teams at each level. By paying attention to how promotions and relegations affect efficiency over the previous year with regard to the elevator teams, the efficiency of these teams improved upon relegation and they remained on the efficient frontier if they remained in the $2^{\text {nd }} \mathrm{A}$ (except on 2 occasions). However, it worsens upon being promoted to the $1^{\text {st }} \mathrm{D}$, although three clubs maintained efficiency for one or two seasons if they were promoted to the $1^{\text {st }} \mathrm{D}$.

\section{Discussion and Conclusion}

Of the number of teams from each level that were efficient in each season, just over half, $58.33 \%$, played in the $1^{\text {st }} \mathrm{D}$. This percentage does not allow us to conclude that it is efficient to play in the first division. In some years, there were more efficient teams in the $2^{\text {nd }} \mathrm{A}$ and in others the same number of teams. As a result, it can be detected that efficiency does not necessarily depend on the level at which the team plays. Based on the results of the DEA, it can be concluded that elevator teams were more efficient in the period analysed than the follower's teams that always played in the $1^{\text {st }} \mathrm{D}$. Further, these were more efficient when they were in the $2^{\text {nd }} \mathrm{A}$. Furthermore, from the description of how promotions and relegations affect efficiency, we can deduce that this efficiency improves and remains higher in the $2^{\text {nd }} \mathrm{A}$ for elevator teams, and as a result, it is better for some teams to remain in the $2^{\text {nd }} \mathrm{A}$ if they want to be efficient. The analysis of the evolution of efficiency with changes in level seems to indicate that when elevator teams are relegated, they carry out containment policies to adjust to new market conditions and thus achieve more balanced management. However, upon winning promotion to the $1^{\text {st }} \mathrm{D}$, while also seeking to remain at this level and to address the barriers to entry to the $1^{\text {st }}$ D, they undertake economic-financial, investment and management and production organization activities that cause them to be inefficient.

It can be deduced from the evaluation of efficiency and its comparison with the sporting classification that most clubs in the Spanish professional league do not achieve sporting success and efficiency simultaneously. Teams aim for a good sporting classification above responsible management. The absence of efficient behaviour generates high indebtedness, insolvency and difficulty surviving for many of them. This is a structural aspect of Spanish football. Only in some seasons was such a relationship observed because efficiency does not depend on sports results. Rather, there is another set of factors to be considered. Some clubs are a reference point in the search for the optimum balance, and it would be useful to study what structural, management, positioning and sports features are required to achieve it.

Using range to describe the efficiency values has been useful to observe the robustness of the results of the chosen nonparametric method (DEA). The selected variables are valid for reflecting trends and robust in detecting efficiency, and therefore, the results of the analysis should be considered. That is, besides sporting aspects, it is necessary to consider heterogeneous factors and variables of the productive structure of the economic and financial management of the club and of the organizational configuration if the goal is to evaluate the efficiency of the SAD and devise strategic options.

The study shows that there is a two-speed league: on one hand, there are leaders, challengers and followers that can maintain their sporting and economic-financial capacity within optimum margins but not always be efficient, and on the other hand, teams that attempt to enter the group of large clubs at a high cost that put their survival at risk. It is necessary that each club adapts to its optimal positioning at one level or another, depending on its productivesporting potential, economic and financial capacity, market scope and organizational structure. It would be desirable that the LFP to harden the economic and financial conditions of promotion and of continuation in $1^{\text {st }} \mathrm{D}$ to solve the structural problem of Spanish football.

It is true that in the current league and its model of promotions and relegation, all teams want to win points to be promoted. Therefore, a formula should be sought to decide which clubs go up a level based on their abilities to address the barriers to enter these levels, the resources they have at their disposal and their borrowing capacity, while also considering that staying in the top 
division is not guaranteed. The league can to serve as an advisor to identify the optimal positioning the clubs. If the club do not want promote, it would be necessary to look rules to maintain the model of competition. Given that and what we have shown in this article, the improvement or maintenance of efficiency can occur without needing to improve sporting successes in any category. Additionally, given that the main objective of every club is achieving good sporting results, organizations should plan strategies to try to achieve a balance between sporting success, efficient management and sustainable growth and decide which position to locate themselves so as not to risk efficiency out of a desire for successful sporting results.

Finding formulas is necessary so that the financial and sporting requirements of much-desired promotion do not create difficulties in terms of budgets, economic-financial matters and management of sporting production. In this regard, the new policies of the LFP, such as financial support for teams that are relegated or the rule that authorizes the LFP an exclusive position in negotiating television rights with subsequent distribution of income between clubs, could contribute to a more balanced competition. It is necessary to reform the $2^{\text {nd }} A$ to make it more attractive to the participants and to facilitate that some equipment, taking advantage of its optimal positioning, remain in $2^{\text {nd }} A$. Moreover, performing longitudinal analyses to identify the dynamics of the efficiency of these organizations, including heterogeneous variables, will allow the evolution of the sector to be observed to decide upon joint policies through the LFP, opening doors to future research.

\section{References}

1. Gerrard B, Dobson S (2000) Testing for monopoly rents in the market for playing talent: Evidence from English professional football. Journal of Economic Studies 27(3): 142-164.

2. Sloane PJ (1971) Scottish journal of political economy: The economics of professional Football: The football club as autility maximiser. Scottish Journal of Political Economy 18(2): 121-146.

3. Dabscheck B (1975a) Sporting equality: Labour market vs. Product market control. Journal of Industrial Relations 17(2): 174-190.

4. Dabscheck B (1975b) The wage determination process for sportsmen. Economic Record 51(1): 52-65.

5. Barajas Á, Rodríguez P (2010) Spanish football clubs' finances: Crisis and player salaries. International Journal of Sport Finance 5(1): 52-66.

6. Soriano F (2012) La pelota no entra por azar: ideas del management desde el mundo del futbol, Aguilar, Madrid.

7. Magaz-González AM (2002) El modelo de competencia del sector de fútbol profesional. Paper Presented at the Congreso Científico Internacional de Fútbol Salamanca, Salamanca, España.

8. Boscá JE, Liern V, Martínez A, Sala R (2009) Increasing offensive or defensive efficiency? An analysis of Italian and Spanish football. Omega 37(1): 63-78.

9. García J, Rodríguez P (2003) From sports clubs to stock companies: The financial structure of football in Spain, 1992-2001. European Sport Management Quarterly 3(4): 253-269.

10. Espitia-Escuer M, García-Cebrián LI (2006) Performance in sports teams: Results and potential in the professional soccer league in Spain. Management Decision 44(8): 1020-1030.
11. Porter PK, Scully GW (1982) Measuring managerial efficiency: The case of baseball. Southern Economic Journal 48(3): 642-650.

12. Haas DJ (2003) Productive efficiency of English football teams-a data envelopment analysis approach. Managerial and Decision Economics 24(5): 403-410.

13. Espitia-Escuer M, Garcĺa-Cebrián LI (2004) Measuring the efficiency of Spanish first-division soccer teams. Journal of Sports Economics 5(4): 329-346.

14. Barros CP, Leach S (2006) Performance evaluation of the English premier football league with data envelopment analysis. Applied Economics 38(12): 1449-1458.

15. Dawson P, Dobson S, Gerrard B (2000) Estimating coaching efficiency in professional team sports: Evidence from English association football. Scottish Journal of Political Economy 47(4): 399-421.

16. Carmichael F, Thomas D, Ward R (2001) Production and efficiency in association football. Journal of Sports Economics 2(3): 228-243.

17. Gerrard B (2005) A resource-utilization model of organizational efficiency in professional sports teams. Journal of Sport Management 19(2): 143-169.

18. Caves RE, Porter ME (1977) From entry barriers to mobility barriers: Conjectural decisions and contrived deterrence to new competition. The Quarterly Journal of Economics 91(2): 241-261.

19. Barney J (1991) Firm resources and sustained competitive advantage. Journal of Management 17(1): 99-120.

20. Penrose E, Pitelis C (2009) The Theory of the Growth of the Firm. OUP Oxford, USA.

21. Peteraf MA (1993) The Cornerstones of competitive advantage: A resource-based view. Strategic Management Journal 14(3): 179-191.

22. Rumelt RP (1991) How much does industry matter? Strategic Management Journal 12(3): 167-185.

23. Wernerfelt B (1984) A resource-based view of the firm. Strategic Management Journal 5(2): 171-180.

24. Boscá JE, Liern V, Martínez A, Sala R (2003) Análisis de la eficiencia técnica de los equipos de las ligas de fútbol profesional' in Congreso Mundial De Gestión Económica Del Deporte SPORTCONGRESS2003, Barcelona, España, pp.1-24.

25. Carmichael F, Thomas D (1995) Production and efficiency in team sports: an investigation of rugby league football.' Applied Economics 27(9): 859-869.

26. López Busto A, Gallardo-Guerrero L, Barajas Alonso A (2010) Aproximaciónal estudio de factores determinantes de la eficiencia de los clubes de fútbol profesional españoles. Paper Presented at the ICongreso Hispano Americano de Economía del Deporte, Gijón, España.

27. Rottenberg S (1956) The baseball player's labor market. The Journal of Political Economy 64(3): 242-258.

28. Zambom-Ferraresi F, García-Cebrián LI, Lera-López F, Iráizoz B (2015) Performance evaluation in the UEFA Champions League. Journal of Sports Economics 18(5): 448-470.

29. Asfour A (2008) Measuring Efficiency of English Premier League Football Teams with a Data Envelopment Analysis Approach. University of Nottingham.

30. Guzmán I (2006) Measuring efficiency and sustainable growth in Spanish football teams. European Sport Management Quarterly 6(3): 267-287.

31. Pestana Barros C, Leach S (2007) Technical efficiency in the English Football Association Premier League with a stochastic cost frontier Applied Economics Letters 14(10): 731-741. 
32. Pestana C, Garcia-del-Barrio P, Leach S (2009) Analysing the technical efficiency of the Spanish Football League First Division with a random frontier model. Applied Economics 41(25): 3239-3247.

33. Charnes A, Cooper WW, Rhodes E (1978) Measuring the efficiency of decision making units. European Journal of Operational Research 2(6): 429-444.

34. Haas D, Kocher MG, Sutter M (2004) Measuring efficiency of German football teams by data envelopment analysise. Central European Journal of Operations Research 12(3): 251-268.

35. Brockett PL, Golany B, Li S (1999) Analysis of intertemporal efficiency trends using rank statistics with an application evaluating the macro economic performance of OECD nations. Journal of Productivity Analysis 11(2): 169-182.
36. Barajas A, Rodríguez P (2012) Insolvencias en el fútbol profesional español: evidencia empírica. In: Calabuig R (Ed.), Economía del deporte en tiempos de crisis. III CIED. Valencia, España, pp.19-22.

37. Espitia-Escuer M, García-Cebrián LI (2005) Eficiencia y equipos de fútbol: son suficientes los recursos para ganar la liga? Revista de empresa: La fuente de ideas del ejecutivo 12: 30-44.

38. Magaz-González AM, Fanjul-Suárez JL (2003) Una aproximación al análisis del sector de fútbol profesonal desde la economía industrial. Anales de economía y administración de empresas (10): 183-225.
Creative Commons Attribution 4.0 International License

For possible submissions Click Here

\section{Submit Article}

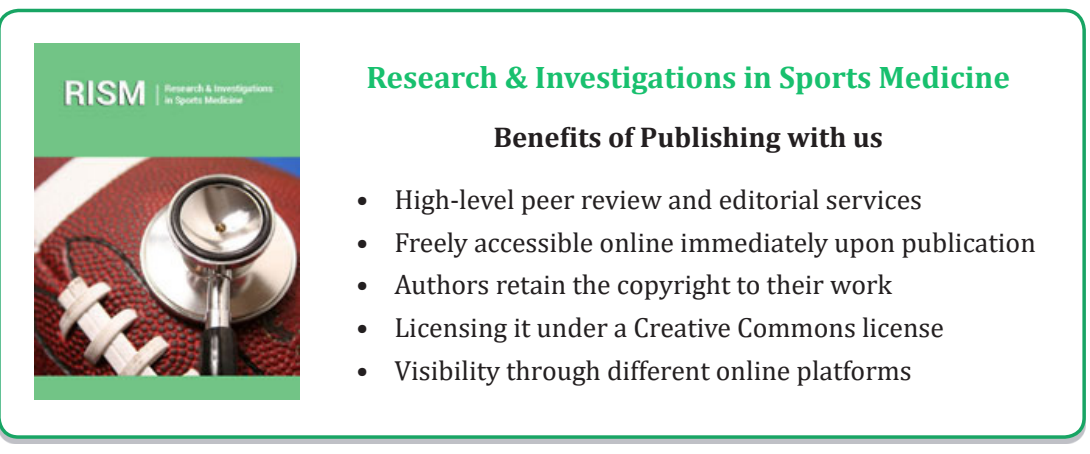

